\title{
Oil generation from coal source rocks: the influence of depositional conditions and stratigraphic age
}

\author{
Henrik I. Petersen
}

Although it was for many years believed that coals could not act as source rocks for commercial oil accumulations, it is today generally accepted that coals can indeed generate and expel commercial quantities of oil. While hydrocarbon generation from coals is less well understood than for marine and lacustrine source rocks, liquid hydrocarbon generation from coals and coaly source rocks is now known from many parts of the world, especially in the Australasian region (MacGregor 1994; Todd et al. 1997). Most of the known large oil accumulations derived from coaly source rocks have been generated from Cenozoic coals, such as in the Gippsland Basin (Australia), the Taranaki Basin (New Zealand), and the Kutei Basin (Indonesia). Permian and Jurassic coal-sourced oils are known from, respectively, the Cooper Basin (Australia) and the Danish North Sea, but in general only minor quantities of oil appear to be related to coals of Permian and Jurassic age. In contrast, Carboniferous coals are only associated with gas, as demonstrated for example by the large gas deposits in the southern North Sea and The Netherlands.

Overall, the oil generation capacity of coals seems to increase from the Carboniferous to the Cenozoic. This suggests a relationship to the evolution of more complex higher land plants through time, such that the highly diversified Cenozoic plant communities in particular have the potential to produce oil-prone coals. In addition to this overall vegetational factor, the depositional conditions of the precursor mires influenced the generation potential.

The various aspects of oil generation from coals have been the focus of research at the Geological Survey of Denmark and Greenland (GEUS) for several years, and recently a worldwide database consisting of more than 500 coals has been the subject of a detailed study that aims to describe the oil window and the generation potential of coals as a function of coal composition and age.

\section{Depositional conditions}

Hydrocarbons are derived from the aliphatic chains in the organic matrix. The dominant organic matter in conventional marine source rocks (type II kerogen), and also lacustrine source rocks (type I kerogen), is formed from algae. This type of organic matter is geochemically quite uniform and contains an abundance of long-chain $n$-alkanes, a prerequi-

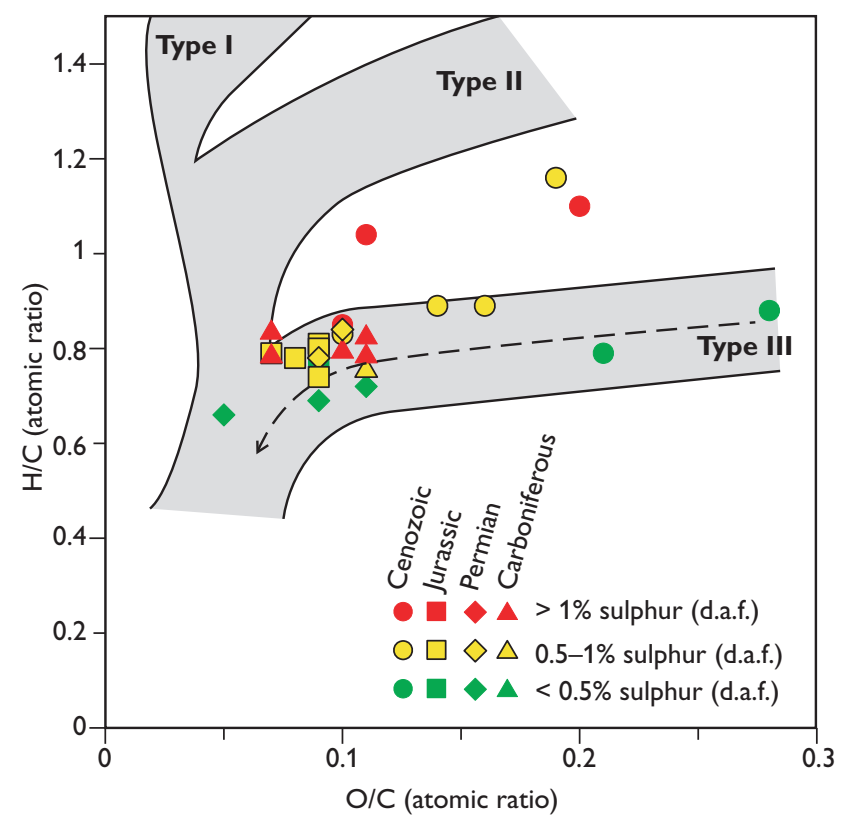

Fig. 1. The H/C ratio of coals from the major coal-forming geological periods displayed on the so-called 'van Krevelen diagram'. Note that coals with a low sulphur content have a tendency to plot towards the lower part of the 'Type III'-band and coals with a higher sulphur content towards the upper limit of the band. This feature is not related to coal age; d.a.f., dry ash-free.

site for oil formation. Coals are composed of transformed higher land plant material (mainly vitrinite or type III kerogen) and are compositionally much more heterogeneous and complex. Compared to algae-derived organic matter, the organic matter is richer in oxygen and contains fewer longchain $n$-alkanes. Therefore coals inherently have lower oil generation potential. However, paralic coals that have been influenced by seawater during deposition may be enriched in hydrogen (higher H/C ratios; Figs 1, 2; Petersen \& Rosenberg 1998; Sykes 2001), and incorporation of the hydrogen into aliphatic chains may increase the generation capacity.

Hydrogen enrichment is related to the activity of sulphate -reducing bacteria, and is commonly associated with increased contents of sulphur (Fig. 1). In the Søgne Basin (North Sea), for example, a clear facies-related change in generation potential is recorded for Middle Jurassic coal source rocks. The coals were formed on marine-influenced coastal 


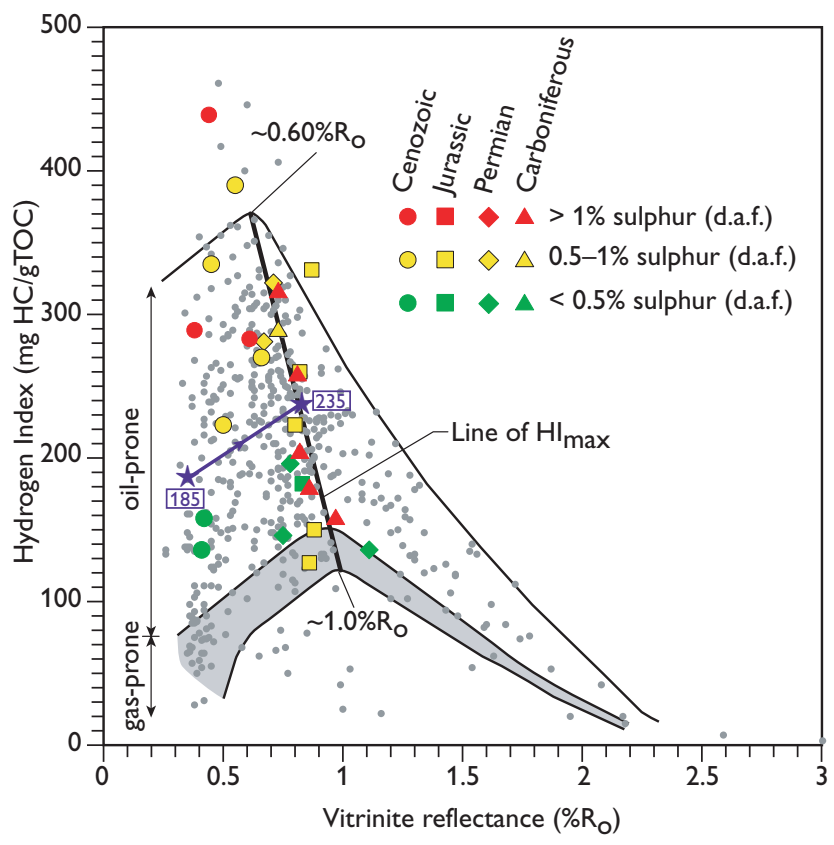

Fig. 2. Evolution in the Hydrogen Index (HI) with increasing maturity shown by 507 coal samples (Petersen in press). Coals with an $\mathrm{HI}<150$ mg HC/g TOC are considered mainly gas-prone (shaded area). Coals with increased sulphur contents have a tendency for higher HI values due to hydrogen-enrichment in the coal-structure. During initial thermal maturation the $\mathrm{HI}$ increases to a maximum value $\left(\mathrm{HI}_{\max }\right)$, which is a better estimate of the true generation potential of a coal. The $\mathrm{HI}_{\max }$ can be estimated by translating the HI value for a coal along its maturation pathway to the $\mathrm{HI}_{\max }$ line (Sykes \& Snowdon 2002); for example the coal with an HI of 185 (blue star) shows a correction of HI by $50 \mathrm{mg} \mathrm{HC} / \mathrm{g}$ TOC $\left(\mathrm{HI}_{\max }=230 \mathrm{mg} \mathrm{HC} / \mathrm{g}\right.$ TOC$)$; d.a.f., dry ash-free.

plains, and the thickest, most landward parts of the coals generated gas and condensate (Harald Field and Trym discovery), whereas the coals that formed close to the palaeo-coastline generated oil (Lulita Field; e.g. Petersen et al. 2000; Petersen $\&$ Brekke 2001). The influence of depositional conditions on the generation potential is independent of coal age (Fig. 2; Petersen in press). The depositional conditions of peat-forming mires may thus help to predict the source rock quality of the coals.

\section{Generation potential}

The evolution of the generation potential (Hydrogen Index = $\mathrm{HI})$ with increasing maturity is shown in Fig. 2. The majority of the coal samples fall within a band that narrows with increasing maturity due the gradual homogenisation of the organic matter. The generation potential is exhausted around a vitrinite reflectance of $2.0 \% \mathrm{R}_{\mathrm{o}}$, but the coals may still possess a considerable potential (HI up to $190 \mathrm{mg} \mathrm{HC/g}$ TOC) at the end of the conventional oil window at about $1.3 \% \mathrm{R}_{\mathrm{o}}$. A prominent feature of the HI-band is the initial increase in
HI up to a maximum HI-value (e.g. Huc et al. 1986; Sykes 2001; Petersen 2002, in press), defined by the $\mathrm{HI}_{\max }$ line between $0.6 \% \mathrm{R}_{\mathrm{o}}$ and $1.0 \% \mathrm{R}_{\mathrm{o}}$. The increase in $\mathrm{HI}$ is caused by the formation of an additional generation potential due to structural reorganisation of the coal matrix, possibly including incorporation of water-derived hydrogen (Lewan 1997; Schenk \& Horsfield 1998). This means that the 'true' generation potential of coals is equivalent to the $\mathrm{HI}_{\max }$, which is derived by translating the coals along their maturation pathway to the maximum value (Fig. 2; Sykes \& Snowdon 2002). Coals with an $\mathrm{HI}_{\max }<150 \mathrm{mg} \mathrm{HC/g}$ TOC are considered to be mainly gas-prone (Fig. 2). Compared to Carboniferous, Permian and Jurassic coals, Cenozoic coals attain the highest $\mathrm{HI}_{\text {max }}$ values $\left(\mathrm{HI}_{\max }=250-370 \mathrm{mg} \mathrm{HC/g}\right.$ TOC; Petersen in press). However, the $\mathrm{HI}_{\max }$ value may not necessarily be an expression of the ability to generate oil. The type of generated petroleum is dependent on the chain length of the $n$-alkanes in the coal structure. The HI is a measure of the hydrogen in the coal, but this may not be present as long-chain $n$-alkanes, but rather as shorter chains with a potential to form only gas or condensate. This may particularly be the case for Carboniferous coals.

Coals with approximately similar HI values should theoretically contain the same proportion of hydrogen and thus have potentially the same petroleum generation capacity. Information about the type of generated petroleum can be obtained by investigating the chain length of the $n$-alkanes in the solid coal structure by Fourier Transform Infrared spectrometry (FTIR) and by ruthenium tetroxide catalysed oxidation. The peak at $2850 \mathrm{~cm}^{-1}$ in the FTIR spectrum is used to estimate the relative proportion of $\mathrm{CH}_{2}$ (dry, ash-free basis), which is taken as a measure of the proportion of oliphatic chains in the coal (Fig. 3). In general, Carboniferous coals contain a lower proportion of $\mathrm{CH}_{2}$ compared to Cenozoic and Jurassic coals with similar HI values. Similarly, the proportion of aliphatic hydrogen is lower for Carboniferous coals (Fig. 3). Cenozoic coals also have significant gas potential (estimated from the $\mathrm{CH}_{3}$ peak at $2955 \mathrm{~cm}^{-1}$ ), which is in good agreement with the coal-sourced South-East Asian oil fields, that commonly also contain significant proportions of gas (e.g. the Kutei Basin, Indonesia). Ruthenium tetroxide catalysed oxidation of the coal structure essentially 'chops' off the aliphatic chains in the coal matrix, which after appropriate chemical treatment can be analysed by gas chromatography - mass spectrometry (GC-MS). By adding an internal standard the obtained chromatograms can be directly compared.

In general, Carboniferous coals contain low proportions of $n$-alkanes with a carbon number $>\mathrm{C}_{19}$, whereas Cenozoic coals in particular are much richer in long-chain aliphatics. The difference in the chemical structure between, for exam- 

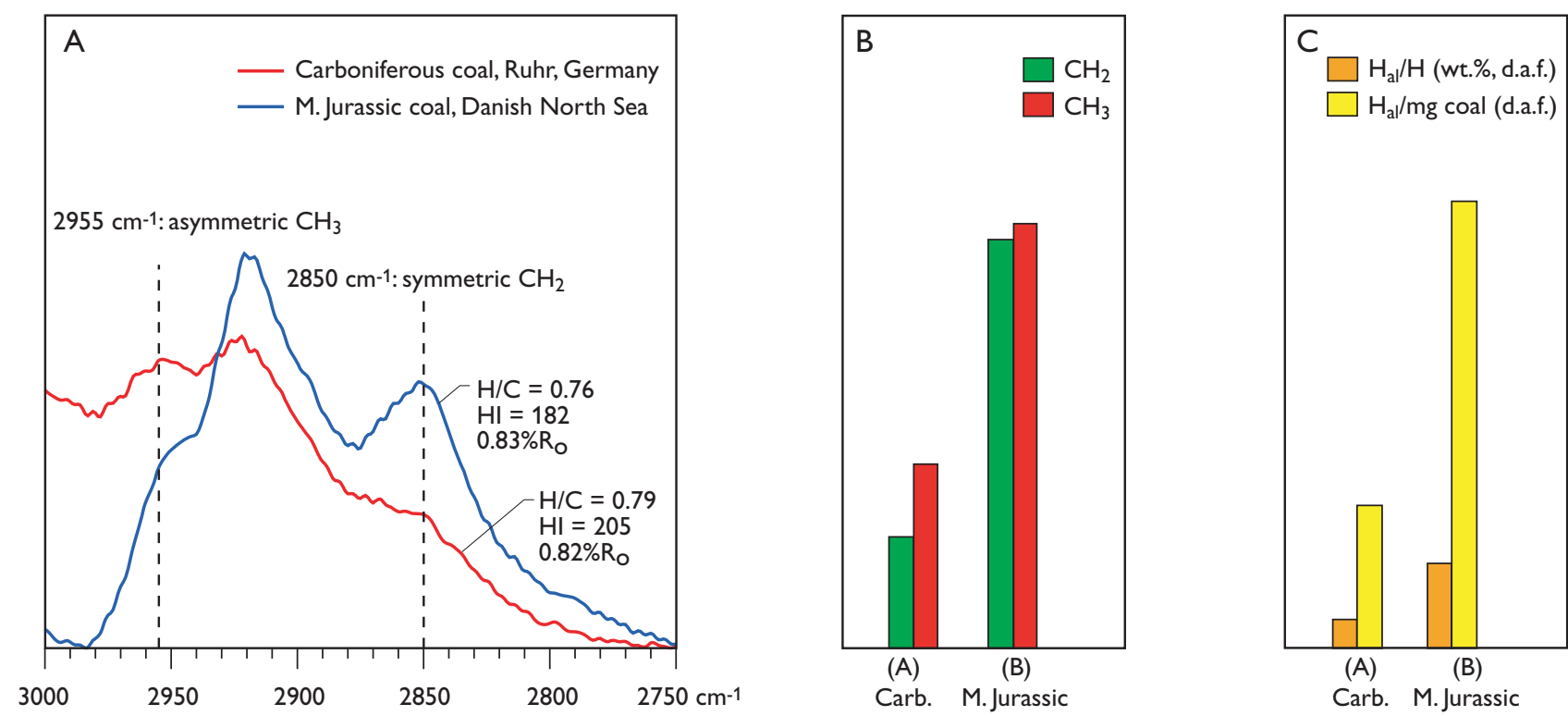

Fig. 3. A: FTIR spectra (aliphatic stretching region) of Carboniferous and Middle Jurassic coals with similar H/C ratios, HI values, and vitrinite reflectances. The Middle Jurassic coal shows a much higher relative response at $2850 \mathrm{~cm}^{-1}$, which is an indication of a higher proportion of aliphatic chains in the coal structure. $\mathbf{B}$ : Calculated relative proportions of aliphatic chains $\left(\mathrm{CH}_{2}\right)$ and $\mathrm{CH}_{3}$. C: Calculated relative proportions of aliphatic hydrogen. The low values for the Carboniferous coal suggest a primary gas generation potential; d.a.f., dry ash-free.

ple, Carboniferous and Cenozoic coals, can be related to the original coal-forming vegetation, and may explain why Carboniferous coals are principally gas- or condensate-prone, whereas Cenozoic coals can be highly oil-prone. In contrast to the Carboniferous woody, gymnospermous mire vegetations, the Cenozoic coals were formed from an advanced and diverse vegetation, which may have produced a more aliphatic-rich vitrinitic organic matter upon deposition.

\section{The effective oil window (oil expulsion window)}

The complex, heterogeneous composition of coals results in a three-phase oil generation model (Fig. 4; Petersen in press): (1) onset of hydrocarbon generation, (2) hydrocarbon buildup in the coal to the expulsion threshold, and (3) oil expulsion in the so-called effective oil window. Figure 4 shows the free hydrocarbons in the coals with increasing maturity. From $0.6-0.7 \%$ Ro to $0.85-1.0 \% \mathrm{R}_{\mathrm{o}}$, the amount of oil increases in the coals up to a maximum value, after which it decreases. This decrease indicates the onset of efficient oil expulsion, and the maximum BI-value thus corresponds to the start of the effective oil window (oil expulsion window). The maturity at which oil expulsion starts and the range of the effective oil window is dependent on the initial generation potential of the coals (Fig. 4). It should, however, be noted that the effective oil window for coals extends to higher maturities than the conventional oil window. Coals generating $<12 \mathrm{mg} \mathrm{HC/g}$

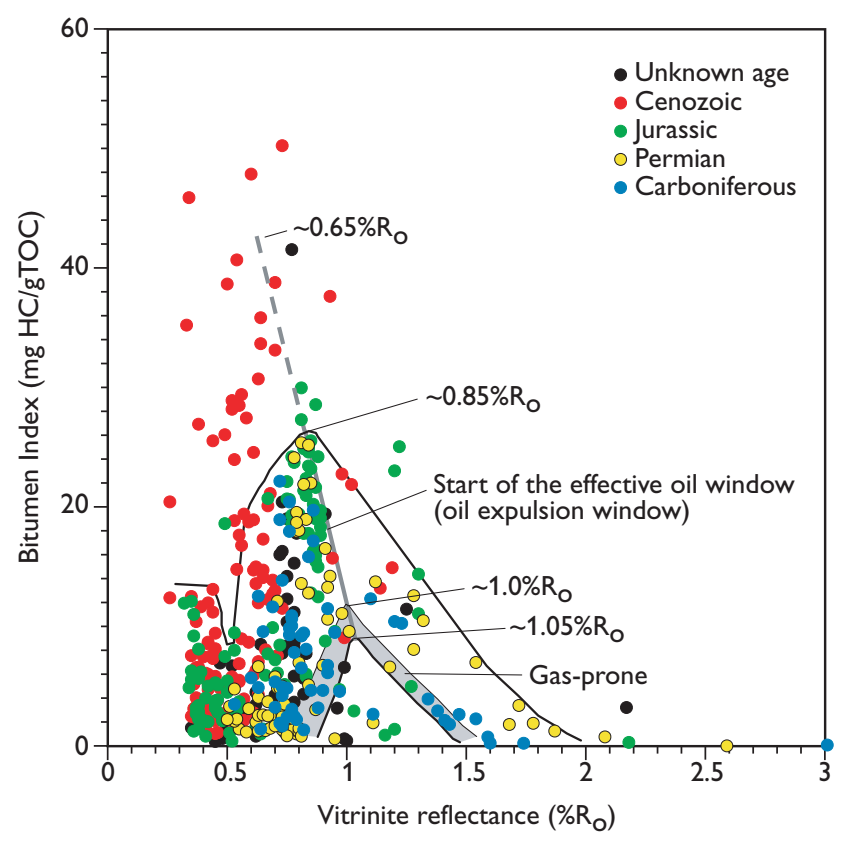

Fig. 4. Evolution in Bitumen Index $\left(B I=S_{1} /\right.$ TOC $)$ with increasing maturity. Initially, hydrocarbons build up in the coal to a maximum value, which indicates the start of the effective oil window. Coals with $<12 \mathrm{mg}$ $\mathrm{HC} / \mathrm{g}$ TOC (shaded area) are considered to have a limited expulsion efficiency (gas-prone). In general, Cenozoic coals generate the highest amounts of hydrocarbons, and they also reach the expulsion threshold at the lowest maturities as shown by the extension of the expulsion line down to $0.65 \% \mathrm{R}_{\mathrm{O}}$. 
TOC are considered to possess a limited oil expulsion efficiency.

Cenozoic coals generate the largest amounts of hydrocarbons and they tend to reach the expulsion threshold at the lowest maturities (from $0.65 \% \mathrm{R}_{\mathrm{o}}$; Fig. 4). The broadest effective oil window is thus related to Cenozoic coals, and may extend from approximately $0.65-2.0 \% \mathrm{R}_{\mathrm{o}}$. Jurassic, Permian and Carboniferous coals reach the start of the effective oil window at higher maturities $\left(0.85-0.9 \% \mathrm{R}_{\mathrm{o}}\right)$. The Jurassic coals show some ability to generate and expel hydrocarbons, whereas several of the Carboniferous and Permian coals seem to have a limited expulsion efficiency; these coals are principally gas-prone. As described above, the organic matter in Carboniferous coals possesses an inherently low ability to generate oil. Hence, the effective oil window for the Carboniferous coals is in reality an effective gas/condensate window.

\section{Conclusion}

Coals can act as source rocks for oil accumulations. The generation potential is related to the depositional conditions of the coal-forming mires, with marine influence having a positive effect by increasing the hydrogen content in the vitrinitic organic matter. In addition, an overall vegetational control seems to be exerted on the source rock potential. Carboniferous coals contain lower proportions of long-chain n-alkanes and aliphatic hydrogen in the coal matrix than younger coals. Cenozoic coals generally contain high proportions of long-chain $n$-alkanes and possess a high oil generation potential in addition to a high gas potential. During maturation, coals form an additional generation potential, and hydrocarbon generation can be described as a three-phase process, including a hydrocarbon build-up phase in the coals before onset of efficient expulsion. The effective oil window starts at higher maturities than the conventional oil window, and in addition extends to higher maturities. Cenozoic coals display the broadest effective oil window, whereas the effective oil window for Carboniferous coals is, in reality, an effective gas/condensate window. This enhanced understanding of oil generation from coal source rocks is being directly employed by GEUS in petroleum geological projects that are being carried out, for example, in Vietnam (cf. Nielsen \& Abatzis 2004).

\section{Acknowledgement}

The Carlsberg Research Foundation (ans-1293 \& ans-1293/20) is thanked for financial support.

\section{References}

Huc, A.Y., Durand, B., Roucachet, J., Vandenbrouke, M. \& Pittion, J.L. 1986: Comparison of three series of organic matter of continental origin. Organic Geochemistry 19, 191-204.

Lewan, M.D. 1997: Experiments on the role of water in petroleum formation. Geochimica et Cosmochimica Acta 61, 3691-3723.

MacGregor, D.S. 1994: Coal-bearing strata as source rocks - a global review. In: Scott, A.C. \& Fleet, A.J. (eds): Coal and coal-bearing strata as oil-prone source rocks? Geological Society Special Publication (London) 77, 107-116.

Nielsen, L.H \& Abatzis, I. 2004: Petroleum potential of sedimentary basins in Vietnam: long-term geoscientific co-operation with the Vietnam Petroleum Institute. Geological Survey of Denmark and Greenland Bulletin 4, 97-100.

Petersen, H.I. 2002: A re-consideration of the 'oil window' for humic coal and kerogen type III source rocks. Journal of Petroleum Geology 25 , 407-432.

Petersen, H.I. in press: The petroleum generation potential and effective oil window of humic coals related to coal composition and age. International Journal of Coal Geology.

Petersen, H.I. \& Brekke, T. 2001: Source rock analysis and petroleum geochemistry of the Trym discovery, Norwegian North Sea: a Middle Jurassic coal-sourced petroleum system. Marine and Petroleum Geology 18, 889-908.

Petersen, H.I. \& Rosenberg, P. 1998: Reflectance retardation (suppression) and source rock properties related to hydrogen-enriched vitrinite in Middle Jurassic coals, Danish North Sea. Journal of Petroleum Geology 21, 247-263.

Petersen, H.I., Andsbjerg, J., Bojesen-Koefoed, J.A. \& Nytoft, H.P. 2000: Coal-generated oil: source rock evaluation and petroleum geochemistry of the Lulita Oilfield, Danish North Sea. Journal of Petroleum Geology 23, 55-90.

Schenk, H.J. \& Horsfield, B. 1998: Using natural maturation series to evaluate the utility of parallel reaction kinetics models: an investigation of Toarcian shales and Carboniferous coals, Germany. Organic Geochemistry 29, 137-154.

Sykes, R. 2001: Depositional and rank controls on the petroleum potential of coaly source rocks. In: Hill, K.C. \& Bernecker, T. (eds): Eastern Australasian Basins Symposium, a refocused energy perspective for the future. Petroleum Exploration Society of Australia Special Publication, 591-601.

Sykes, R. \& Snowdon, L.R. 2002: Guidelines for assessing the petroleum potential of coaly source rocks using Rock-Eval pyrolysis. Organic Geochemistry 33, 1441-1455.

Todd, S.P., Dunn, M.E. \& Barwise, A.J.G. 1997: Characterizing petroleum charge systems in the Tertiary of SE Asia. In: Fraser, A.J., Matthews, S.J. \& Murphy, R.W. (eds): Petroleum geology of Southeast Asia. Geological Society Special Publication (London) 126, 25-47.

\section{Author's address}

Geological Survey of Denmark and Greenland, Øster Voldgade 10, DK-1350 Copenhagen K, Denmark. E-mail: hip@geus.dk 